\title{
The Importance of Corporate Social Responsibility and Financial Performance for the Value of Banking Companies in Indonesia
}

\author{
Submitted 11/01/19, 1st revision 14/02/19, 2nd revision 30/03/19, accepted 15/04/19 \\ Dwi Ermayanti Susilo ${ }^{1}$, Grahita Chandrarin ${ }^{2}$, Boge Triatmanto ${ }^{3}$
}

\begin{abstract}
:
Purpose: This study aims to determine the influence of the importance of corporate social responsibility and financial performance to the value of banking companies in Indonesia.

Design/Methodology/Approach: This research was conducted on 30 companies engaged in Banking in Indonesia listing on JSE 2010-2016.

Findings: The results show that corporate social responsibility and financial performance have influenced the value firm of banking companies in Indonesia.

Practical Implications: Indonesian banks must strengthen their capital structure and improve efficiency in order to compete with foreign banks. The company's goal is to increase the company's value or the growth of the company.

Originality/Value: The results highlighted that the higher the value of corporate social responsibility issued by the company the better the performance of the company, the better the value of firm generated by Indonesian Banking companies.
\end{abstract}

Keywords: Corporate social responsibility, financial performance, corporate value.

JEL Codes: M48, M49.

Paper Type: Research paper.

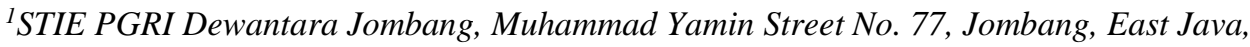
Indonesia, email: dwiermayani.stiedewantara@gmail.com

${ }^{2}$ STIE PGRI Dewantara Jombang, Muhammad Yamin Street No. 77, Jombang, East Java, Indonesia

${ }^{3}$ Universitas Merdeka Malang, Terusan Dieng Street No. 62-64, Malang, East Java, Indonesia
} 


\section{Introduction}

The large number of human resources in Indonesian banking that are not ready to face the changing global business management and the lack of competitiveness encourage the central government to take aggressive policies for the advancement of Indonesian banking. This due to the condition of the go-public banking is required to provide the best financial performance, which can be seen in stock prices in the stock market, especially if the stocks have high liquidity. If the stock is less attractive to the market, then there is a tendency of poor earnings management. This can affect the value of the company therefore should be evaluated corporate strategy so that companies can more easily make improvements in case of decline in earnings and stock prices.

Indonesian banks, should strengthen their capital structure and improve efficiency in order to face competition with foreign banks because the market share of foreign banks will be more if the national banking industry does not improve its power. Mergers or acquisitions are a powerful way to improve efficiency. It will make the composition of directors more streamlined and pruning branch offices. Especially for the Indonesian market, local banks should be better prepared because they already have enough segmentation. While foreign banks still need time to dominate the Indonesian market. Nevertheless, the government should think that local banks not only control the local market, but also can expand in ASEAN. Banking in Indonesia can provide Corporate Social Responsibility to the community that can support the program in various aspects of community life such as education, health, cultural arts, sports and religion.

According to Sujoko and and Soebiataro (2007), the value of the company is the perception of investors to the success rate of the company that is closely related to the stock price. High stock prices make the company's value also high, and increase market confidence not only to the current financial performance but also on the prospect of the company in the future. The price of shares used generally refers to the closing price, and is the price that occurs when the stock is traded on the market (Fakhruddin, 2001). The company's goal is to increase the company's value or the growth of the company. The company's visible growth is the high valuation of the company's external to its assets and to the growth of the stock market (Enrique and de Oro Celestino, 2007). The value of a firm is a price that is available in case the company is sold. Company value can be reflected through the stock price. The higher the stock price means the higher the rate of return to the investor and that means the higher the company's value is also related to the purpose of the company itself, that is to maximize shareholder wealth (Gultom, 2008).

Financial performance is an analysis conducted to see the extent to which a company has implemented by using the rules of financial implementation properly and correctly. Company performance is a description of the financial condition of a company that is analyzed with the tools of financial analysis, so it can be known 
about both the poor financial condition of a company that reflects the performance of work within a certain period. It is very important that resources are used optimally in the face of environmental change (Fahmi, 2011). Assessment of financial performance is one way that can be done by the management in order to fulfill its obligations to the funders and also to achieve the goals set by the company (Rahayu, 2015).

According to the World Business Council for Sustainable Development, CSR is an ongoing commitment by businesses to act ethically and contribute to the economic development of the local community or society at large (D'Amato, 2007), along with improving the standard of living of workers and the whole family (Ismail, 2007). CSR is the responsibility of an organization to the impacts of its decisions and activities on society and the environment embodied in the form of transparent and ethical behavior in line with sustainable development and public welfare, taking into account the expectations of stakeholders, in line with established laws and international behavior norms integrated with the organization as a whole (Fama, 1978; Susilo, 2018).

\section{Conceptual Framework}

The information contained in the company's financial statements plays an important role in the capital market, both for individual investors and for the market as a whole. In line with that CSR is one of the obligations that must be implemented by the company (Bassamalah, 2005). The industry or cooperative is obliged to carry it out, but this obligation is not a burdensome burden. Keep in mind the development of a country is not only the responsibility of government and industry alone, but every human being plays a role to realize social welfare and management of the quality of life of the community. Based on the description above, the concept of this research can be described as in the picture of the conceptual framework in Figure 1. People today are smarter in choosing the products they will consume, so they choose products produced by companies that care about the environment and or implement CSR. A survey conducted by Ismail (2009) indicates that the majority of consumers will leave a product that has a bad image or reported negated. Many benefits obtained by the company by implementing CSR, among other products will be preferred by consumers, companies and interested investors (Morais Pereira et al., 2018; Mahboud, 2017).

Investors overview a company by looking at financial ratios as an investment evaluation tool, as financial ratios reflect the high or the low value of the firm. If investors want to see how big companies generate return on investments they make, the first thing to see is the profitability ratio. Profitability can be produced through Return on Assets (ROA) and Return on Equity (ROE). ROA and ROE are two of the profit ratios. The higher this ratio, the greater the profitability of the company, which in turn can be a positive signal for investors in investing to obtain a certain return. The rate of return obtained illustrates how well the firm values in the eyes of 
The Importance of Corporate Social Responsibility and Financial Performance for the Value of Banking Companies in Indonesia

234

investors. If companies managed to record a large profit rate, then this will motivate investors to invest in stocks, so that stock prices and demand will increase (Keown, 2005).

Figure 1. Conceptual Framework

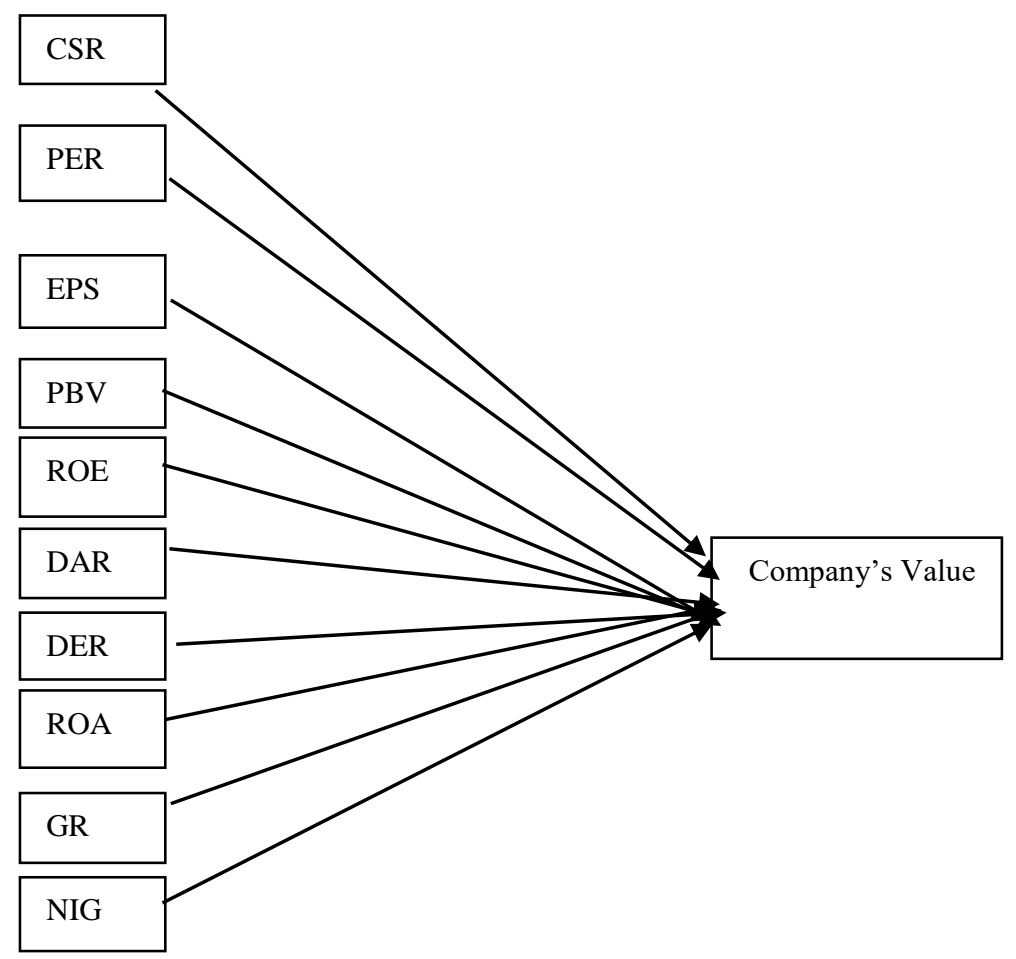

Table 1. Speculate Variables, Indicators and Research Items

\begin{tabular}{|c|c|c|}
\hline Variable & Indicator & Item \\
\hline Corporate Value & EVA & $\begin{array}{l}\text { 1. Net Operating After Tax } \\
\text { 2. The Average Capital Cost is Weighted } \\
\text { 3. Capital } \\
\text { 4. Debt Costs } \\
\text { 5. The Cost of Ordinary Share Capital } \\
\text { 6. The Cost of Preferred Stock Capital } \\
\text { 7. Number of Shares Outstanding } \\
\text { 8. Stock Price is Outstanding } \\
\text { 9. Total Capital }\end{array}$ \\
\hline $\begin{array}{l}\text { Financial } \\
\text { Performance }\end{array}$ & $\begin{array}{l}\text { Financial } \\
\text { Analysis }\end{array}$ & $\begin{array}{ll}\text { 1. } & \text { Price Earning Ratio } \\
\text { 2. } & \text { Price Book Value } \\
\text { 3. } & \text { Earning Per Share } \\
\text { 4. } & \text { Return on Total Asset } \\
\text { 5. } & \text { Return on Equity }\end{array}$ \\
\hline
\end{tabular}




\begin{tabular}{|l|l|l|}
\hline & & 6. Debt to Total Asset Ratio \\
& & $\begin{array}{l}\text { 7. Debt to Equity Ratio } \\
\end{array}$ \\
& & 8. Growth of Revenue \\
& & CSet Income Growth \\
\hline CSR & Social & CSR Fund \\
\hline
\end{tabular}

\section{Results}

\subsection{Classic Assumption Test}

Table 1 shows the significance value of the Kolmogorov-Smirnov one sample test being 0.000 less than $\alpha(0.05)$. Accordingly, the decision to reject $\mathrm{H} 0$ means that the distribution of abnormal distributed residuals is significant (Table 2). Moreover, testing the multicollinearity shows that all VIF values of each independent variable is less than 10 with a tolerance value greater than 0.1 , which means that between independent variables there is not a strong correlation or no multicollinearity (assumption is met).

A test of heterocedasticity aims to test whether the regression model has the same residual variance or not, and the test shows that the assumption of heteroscedasticity is met (homogenous residuals). In terms of the autocorrelation test, the DurbinWatson test statistic is used, and the test shows that there is no autocorrelation between residuals (Table 3 ).

Table 2. One Sample Kolmogorov-Smirnov Test

\begin{tabular}{|c|c|}
\hline Residual & Significance \\
\hline Model 1 & 0.000 \\
\hline
\end{tabular}

Table 3. Autocorrelation Test with Durbin Watson

\begin{tabular}{|l|l|l|l|l|}
\hline $\mathrm{d}_{\mathrm{L}}$ & $\mathrm{d}_{\mathrm{U}}$ & $\mathrm{DW}$ & $4-\mathrm{d}_{\mathrm{U}}$ & $4-\mathrm{d}_{\mathrm{L}}$ \\
\hline 1.675 & 1.863 & 1.910 & 2.137 & 2.325 \\
\hline
\end{tabular}

\subsection{Multiple Regression Analysis}

Further regression analysis is used to obtain the effect of the independent variables (PER, PBV, EPS, ROA, ROE, DAR, DER, GR, NIG, and CSR) to dependent variable. In processing the data by using multiple linear regression analysis, conducted in several stages to find the relationship between independent and dependent variable results are presented in Table 4. Thus, the obtained regression model is as follows: 
The Importance of Corporate Social Responsibility and Financial Performance for the Value of Banking Companies in Indonesia

$E V A=-4.92 \times 1013-1.72 \times 1010 P E R+7.45 \times 1012 P B V+1.21 \times 1010 E P S+$ $6.29 \times 1012 \mathrm{ROA}-5.17 \times 1011 \mathrm{ROE}+3.93 \times 1013 \mathrm{DAR}+2.39 \times 1011 \mathrm{DER}+$ $2.53 \times 108 \mathrm{NIG}+1.02 \times 1011 \mathrm{CSR}+e \mathrm{i}$

Table 4. Summary of Multiple Linear Regression Test

\begin{tabular}{|l|l|l|l|l|}
\hline \multicolumn{1}{|c|}{ Variable } & \multicolumn{1}{|c|}{$\mathrm{B}$} & $\mathrm{T}_{\text {count }}$ & Significance & \multicolumn{1}{|c|}{ Notes } \\
\hline Constant & -49187583518078.610 & & & \\
\hline PER & -17265699656.007 & -4.144 & 0.047 & Significant \\
\hline PBV & 7446917772233.262 & 1.973 & 0.014 & Significant \\
\hline EPS & 12146924389.962 & 0.442 & 0.659 & Not Significant \\
\hline ROA & 6287264971118.771 & 0.684 & 0.495 & Not Significant \\
\hline ROE & -517381014803.791 & -0.996 & 0.057 & Significant \\
\hline DAR & 39273370135678.160 & 0.504 & 0.615 & Not Significant \\
\hline DER & 238625192709.564 & 1.999 & 0.013 & Significant \\
\hline NIG & 253088003.080 & 0.031 & 0.976 & Not Significant \\
\hline CSR & 101915840061.023 & 0.053 & 0.005 & Significant \\
\hline A & $=0.050$ & & \\
\hline Correlation Coefficient $(\mathrm{R})$ & $=0.788$ & & \\
\hline Determination Coefficient $\left(\mathrm{R}^{2}\right)$ & $=0.620$ & \\
\hline F-count & $=1.960$ & \\
\hline F-table $\left(\mathrm{F}_{9,193.0 .05}\right)$ & $=1.929$ & 0.046 \\
\hline Significance $\mathrm{F}$ & $=1.972$ & \\
\hline t-table $\left(\mathrm{t}_{193,0.05}\right)$ &
\end{tabular}

\section{Discussion}

Partial regression model test is used to find out whether each independent variable forming regression model individually has a significant influence on the dependent variable. To test the relationship, $\mathrm{t}$ test is used, that is by comparing $\mathrm{t}$-count with $\mathrm{t}$ table. Independent variable forming regression model is said to have significant effect if t-estimated $>\mathrm{t}$-table or significant level $<\alpha=0.05$.

Based on statistical test, the results show that the variable of PER has positive and significant influence to EVA variable because test statistic value with $t$-count is greater than t-table $(4.144>1.972)$ and significance value smaller than $\alpha=0.05$ $(0.047<0.05)$. Therefore, $\mathrm{H} 0$ is rejected.

Secondly, PBV variable has positive and significant effect to EVA variable because test statistic value with $\mathrm{t}$-count is bigger than $\mathrm{t}$-table $(1.973>1.972)$ and significant value smaller than $\alpha=0.05(0.014<0.05)$. Therefore, $\mathrm{H} 0$ is rejected.

Thirdly, Y13 variable (EPS) has positive and insignificant effect to EVA variable because test statistic value with $\mathrm{t}$-count is smaller than $\mathrm{t}$-table $(0.442<1.972)$ and significant value greater than $\alpha=0.05(0.659>0.050)$. Therefore, H0 is accepted, however this effect is insignificant.

Fourth, Y14 variable (ROA) has positive and not significant effect to EVA variable because test statistic value with t-count is smaller than t-table $(0.684<1.972)$ and significant value greater than $\alpha=0.05(0.495>0.05)$. Therefore, H0 is accepted, however this effect is insignificant. 
Fifth, Y15 variable (ROE) has positive and significant effect to EVA variable because test statistic value with $\mathrm{t}$-count is smaller than t-table $(0.996<1.972)$ and significant value greater than $\alpha=0.05(0.057>0.050)$. Therefore, H0 is accepted.

Sixth, Y16 variable (DAR) has positive and insignificant effect to EVA variable because test statistic value with $\mathrm{t}$-count is smaller than t-table $(0.504<1.972)$ and significant value greater than $\alpha=0.05(0.615>0.050)$. Therefore, H0 is accepted, however this effect is insignificant.

Seventh, Y17 variable (DER) has positive and significant effect to EVA variable because test statistic value with $\mathrm{t}$-count is smaller than t-table $(1.199<1.972)$ and significant value smaller than $\alpha=0.05(0.013<0.05)$. Therefore, $\mathrm{H} 0$ is rejected.

Eighth, Y18 variable (NIG) has positive and insignificant effect to EVA variable because test statistic value with t-count is smaller than t-table $(0.031<1.972)$ and significant value greater than $\alpha=0.05(0.976>0.050)$. Therefore, H0 is accepted, however this effect is insignificant.

Lastly, CSR variable has positive and significant effect to EVA variable because test statistic value with t-count is greater than t-table $(1.989>1.972)$ and significant value $t$ smaller than $\alpha=0.05(0.005<0.050)$. Therefore, H0 is rejected.

In terms of simultaneous testing, it was performed to show whether all the variables used in the regression model had a significant effect on the EVA variable. All variables are tested simultaneously by using the F test. Statistical analysis shows that the value of F-count is less than F-table $(0.600<1.929)$ and has a significance value of 0.046 which is smaller than $\alpha=0.05$, so $\mathrm{H} 0$ is rejected. This means that simultaneously, the independent variables of PER, PBV, EPS, ROA, ROE, DAR, DER, GR, NIG, and CSR significantly influence the EVA variable.

Finally, the coefficient of determination (R2) is a measure of the accuracy or suitability of the regression line obtained from the result of parameter estimation based on the example. The amount of contribution from independent variables simultaneously to the dependent variable, based on the calculation results in Table 4 with the value of coefficient of determination ( $\mathrm{R}$ Square) being 0.788 . These results show that the contribution of the independent variables (PER, PBV, EPS, ROA, ROE, DAR, DER, GR, NIG, and CSR1) included in the regression equation to the EVA variable is $62 \%$, while the remaining $38 \%$ is contributed to other variables not included in this equation.

\section{Conclusion}

Indonesian banks, must strengthen their capital structure and improve efficiency in order to compete with foreign banks. The company's goal is to increase the company's value or the growth of the company. The company's visible growth is the high valuation of the company's external to its assets and to the growth of the stock market. CSR is the responsibility of an organization for the impacts of its decisions and activities on society and the environment embodied in the form of transparent 
and ethical behavior in line with sustainable development and community welfare. The results of this study show that Corporate Social Responsibility has an influence on value firm banking companies in Indonesia, supporting the idea that the more Corporate Social Responsibility value issued by the company, the greater the Value Firm generated, because by providing Corporate Social Responsibility the company can attract the public interest, especially customers to be more loyal to Indonesian banking. Moreover, financial performance has an influence on Value Firm of banking companies in Indonesia. The amount of financial performance affects the value of the company, so the higher the financial performance of the company the higher the company value.

\section{References:}

Basalamah, A.S. and Jermias, J. 2005. Social and environmental reporting and auditing in Indonesia: maintaining organizational legitimacy? Gadjah Mada International Journal of Business, 7(1), 109-127.

D'amato, A., Henderson, S. and Florence, S. 2009. Corporate social responsibility and sustainable business. A Guide to Leadership tasks and functions, 102.

Enrique Valladares Soler, L. and Jesús Cuello de Oro Celestino, D. 2007. Evaluating the scope of IC in firms' value. Journal of Intellectual Capital, 8(3), 470-493.

Fahmi, I. 2011. Analysis of Financial Statements. Lampulo: Alfabeta.

Fama, E.F. 1978. The effects of a firm's investment and financing decisions on the welfare of its security holders. The American Economic Review, 68(3), 272-284.

Fakhruddin, M. and Hadianto, M.S. 2001. Tools and Models of Investment Analysis in the Capital Market. Jakarta: Elex Media Komputindo.

Gultom, C.M. 2008. Effect of Leverage Policy, Dividend Policy and Earnings Per Share on Company Values in Manufacturing Companies Listed on the Indonesia Stock Exchange. Journal of Accounting, 47.

Hidayat, A. 2013. Effects of Debt Policy and Dividend Policy on Corporate Values (Empirical Study on Manufacturing Companies listed on the IDX). Jurnal Akuntansi, 1(3).

Ismail, M. 2009. Corporate Social Responsibility and its role in community development: An international perspective. Journal of International social research, 2(9).

Ismail, M. 2009. The gendered nature of careers: Evidence from a Malaysian university. Journal of International Management Studies, 4(2), 175-184.

Keown, A.J., Martin, J.D., Petty, J.W. and Scott, D.F. 2005. Financial management: Principles and applications. Pearson Education International.

Mahboud, R. 2017. Main Determinants of Financial Reporting Quality in the Lebanese Banking Sector. European Research Studies Journal, 20(4B), 706-726.

Morais Pereira, M.V., Candeias Bonito Filipe, A.J. 2018. Quality of Board Members' Training and Bank Financial Performance: Evidence from Portugal. International Journal of Economics \& Business Administration, 6(3), 47-79.

Sujoko and Soebiataro, U. 2007. Shareholding Structure Influence Leverage Factor Internal and External Factors Against Value Company (Empirical Study on the Manufacturing and Non-Manufacturing Companies in Jakarta Stock Exchange). Journal of Management and Entrepreneurship, 9(1976), 41-48.

Susilo, D.E. 2018. The Effects of Corporate Social Responsibility on Corporate Value. Arthatama Journal of Business Management and Accounting, 2(1). 